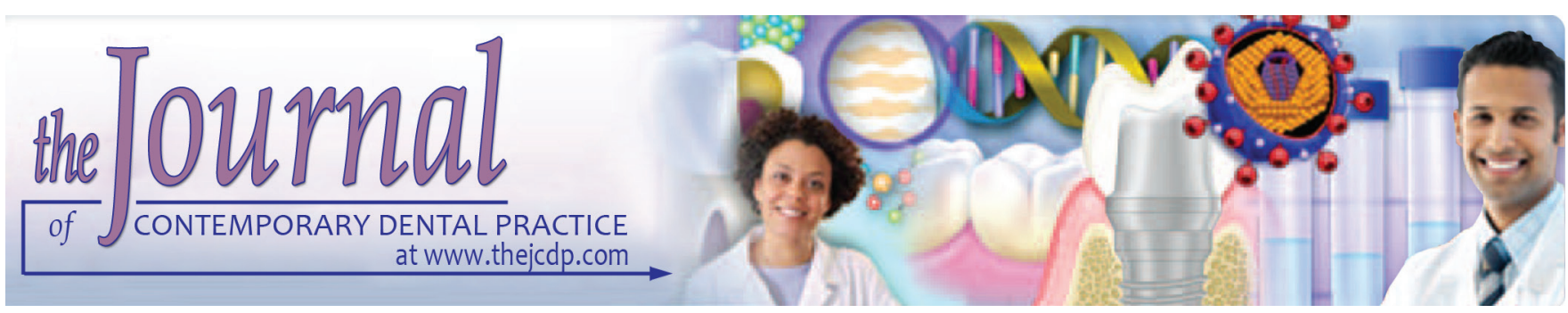

\title{
Utility of Dermatoglyphic Pattern in Prediction of Caries in Children of Telangana Region, India
}

\author{
${ }^{1}$ Shaik M Asif, ${ }^{2}$ Dara BG Babu, ${ }^{3}$ Shaik Naheeda
}

\begin{abstract}
Introduction: Dermatoglyphics is an extremely useful tool as a preliminary investigation method for diagnosing suspected genetic disorders. Caries being a multifactorial disease with the influence of genetic pattern, early identification of caries risk children with dermatoglyphics can help in using effective and efficient caries preventive measures.
\end{abstract}

Aims and objectives: The study was undertaken to record and know the frequency of occurrence of fingerprint patterns among children with caries and in children without caries.

Materials and methods: A total of 400 schoolchildren in the age group of 5 to 12 years were selected from a private school, Warangal, Telangana, India. Of 400 schoolchildren, 200 children were with caries group and 200 children were in caries-free group. Children with dental caries in five or more teeth based on the decayed, missing, filled teeth index performed were considered as study group, and the control group was normal healthy children without any dental caries. The fingerprints of each child were recorded using stamp pad method, and type of dermatoglyphic pattern of each digit was recorded based on Cummins and Midlo method. Data obtained were put for statistical analysis; $p<0.001$ was considered statistically significant.

Results: Although the frequency of whorl pattern was more prevalent in caries group, it was statistically significant on the left hand third digit of females and on the right hand third digit and the left hand fourth digit of males. Fingerprints of female caries-free group showed maximum of ulnar loop and males showed maximum of arches. There was a decrease in total ridge count in caries group, especially in males.

${ }^{1}$ Department of Oral Medicine and Radiology, Pacific Academy of Higher Education \& Research University, Udaipur, Rajasthan India

2Department of Oral Medicine \& Radiology, Panineeya Institute of Dental Science \& Research Centre Hyderabad, Telangana, India

${ }^{3}$ Department of Periodontology, KIMS Dental College Amalapuram, Andhra Pradesh, India

Corresponding Author: Shaik M Asif, Department of Oral Medicine and Radiology, Pacific University Udaipur, Rajasthan India, Phone: +918125660749, e-mail: masif020@gmail.com
Conclusion: Dermatoglyphics could be an appropriate method to explore the possibility of a noninvasive and an early predictor for dental caries.

Clinical significance: Dermatoglyphics has a future role in identifying people with or at increased risk for dental caries so that risk reduction measures or earlier therapy may be instituted.

Keywords: Dental caries, Dermatoglyphics, Fingerprints.

How to cite this article: Asif SM, Balaji Babu DBG, Naheeda S. Utility of Dermatoglyphic Pattern in Prediction of Caries in Children of Telangana Region, India. J Contemp Dent Pract 2017;18(6):490-496.

Source of support: Nil

Conflict of interest: None

\section{INTRODUCTION}

Dental caries is a microbial disease of the calcified tissues of the teeth, characterized by demineralization of the inorganic portion and destruction of the organic substance of the tooth. It is the most prevalent chronic disease affecting the human race. It is five times more common than asthma and seven times more common than hay fever. It is said that once it occurs, the scars persist throughout life even though the lesion is treated. Nowadays, all experts on dental caries agree that it is a multifactorial disease and also an infectious and communicable disease. ${ }^{1}$ There are practically no geographic areas in the world whose inhabitants do not exhibit some evidence of dental caries. It affects both sexes, in all races, all socioeconomic strata, and in every age group, though some people are more prone to it. ${ }^{2}$ The cost involved in treating the disease in terms of manpower and the hours spent is enormous. Furthermore, the excruciating pain experienced by the patient can affect the patient as much as esthetic problem it poses. Systemic complications, such as subacute bacterial endocarditis, have also been documented with caries. ${ }^{3}$ Caries in infants and young children has long been recognized as a clinical syndrome and described as early as middle of last century. 
Beltrami characterized this pattern of early caries in young children in 1930 as "les dents noire de tout petis" or literally translated "black teeth of the very young." ${ }^{4}$ There are various methods to diagnose early childhood caries. But so far, there is no method to predict the same. The epithelium of finger buds as well as enamel, which is the most susceptible dental tissue to dental caries, has ectodermal origin and both develop at the same time of intrauterine (IU) life. Several studies have shown that dermatoglyphic patterns are genetically determined. Hence, any problem at this particular period will have its effect on both the enamel and on the dermatoglyphic patterns.

Dermatoglyphics - the study of pattern traceries of fine ridges of fingers, palm, and sole - has been a useful tool. It proved important due to the fact that (1) unlike most human tracts, dermal ridges and configurations formed by them are not affected by age; (2) detailed structure of individual ridges is extremely variable; and (3) throughout postnatal life they are not affected by environment. ${ }^{5}$ The first "official" mention of fingerprints (1684) was put forward by Dr Nehemiah Grew in his lectures to the Royal College of Physicians of London about the interesting markings found on human fingertips. The first classification of fingerprints was put forward by John E Purkunje, Professor of Anatomy at the University of Breslau in 1823. He classified fingerprints into nine basic patterns. The usage of fingerprints for criminal investigation was first done by Dr Henry Faulds Tsukji Hospital, Tokyo, in 1880. In 1892, Sir Francis Galton, anthropologist, cousin of Charles Darwin, published "Finger Prints," which is one of the landmark publications. If Cummins is the father of dermatoglyphics, Galton is the "inventor." He put forward the first practical method of fingerprint identification responsible for basic nomenclature (arch, loop, whorl). ${ }^{6-8}$ Dermatoglyphics is still not considered as an independent field of study, though there are bodies of theories, methods, and applications. It is still considered as an adjunct to other disciplines, serving as a vehicle to resolve broader biomedical problems.

Dermatoglyphics in the present era is proving itself as an important aid for preliminary investigations in conditions with a suspected genetic basis., ${ }^{3,9}$ In the present work, the study was undertaken to record and know the frequency of occurrence of fingerprint patterns among children with caries and in children without caries.

\section{MATERIALS AND METHODS}

\section{Case Selection}

\section{Details of the Pilot Study}

A pilot study was conducted to determine the sample size of the study population based on the results obtained and to check the feasibility of the study and note any difficulties encountered during the examination. This pilot study helped in exacting the predesigned pro forma and to make modifications wherever necessary to design the final pro forma. The pilot study subjects were not included in the main study. After conducting the pilot study, the prevalence of caries was assessed and the sample size was attained as follows:

$$
\begin{gathered}
N=\frac{Z^{2} \times P(1-P)}{d^{2}} \\
D \text { is the precision }=5 \% \\
P \text { is the prevalence }=15 \% \\
Z \text { is the level of confidence }=95 \%
\end{gathered}
$$

The sample size is estimated to be 196, which can be approximated to 200.

Children in the age group of 5 to 12 years were examined and the decayed, missing, filled teeth (DMFT) recording was done with mouth mirror by natural illumination. In the study, 400 patients (200 controls +200 tests) participated. School principal gave permission to conduct the study, and ethical clearance was obtained from ethical review committee of the institution. A week before the study, parents were intimated. Assurance was given that children's fingerprint will be maintained confidentially and used only for this study. After taking permission, children were included in the study. A sample number was designated for each child and that same number was used for identification on their recording sheet and separate sheet was used to write DMFT index along with their sample number. The study group included children with dental caries in five or more teeth based on DMFT index and control group consisted of children without any dental caries.

\section{Inclusion Criteria}

Children with dental caries among age group of 5 to 12 years were selected from Shine High School, Warangal, Telangana, India, for the study.

\section{Exclusion Criteria}

Children with skin disorders, systemic disease, physical and mental incompatibility, and uncooperative patients were excluded from the study.

\section{Dermatoglyphic Pattern Recording and Interpretation}

Recording of fingerprint patterns of the study subject was achieved with a rolling impression technique using printer's ink, as similarly done by Tikare et al. ${ }^{10}$ To avoid duplication of fingerprints, the fingers were numbered from 1 to 5 for left little finger to the thumb, and from 6 to 10 for right thumb to right little finger of the hand 
respectively. The hands were cleaned with soap and water and then scrubbed thoroughly with an antiseptic lotion (Savlon) and allowed to dry. This was done to enhance the quality of fingerprints by removing sweat and dirt from the skin surface.

The ink stamp pad method was used to record the handprints. First, handprints of four digits were taken together. Thumb does not provide proper prints since humans have an opposable thumb, thus a different spatial orientation with other fingers. Hence, thumbs were recorded separately.

The fingerprints were then verified and the whole procedure was repeated to ensure proper recording of the fingerprints. The obtained dermatoglyphic patterns for fingertips, i.e., presence of arches, loops, and whorls, were assessed with the help of magnifying glass $(\times 10)$ with respect to available standards and data were tabulated.

\section{Total Ridge Count}

The total ridge count was done by marking two landmarks that are "core" and "triradii" of the pattern. The ridges crossing core and triradii were counted, whereas the ridges terminating prior to touching the line were excluded from the study. The ridges of core and triradii were not included. If a ridge bifurcates before reaching the line, they are counted as two ridges.

\section{RESULTS}

This study was undertaken to evaluate the fingerprint patterns of patients diagnosed with dental caries and caries-free children. A total of 400 schoolchildren were included in the study after obtaining informed consent for participation in the study. Among caries group, 115 (58\%) were boys and 85 (42\%) were girls and similarly $115(58 \%)$ were boys and 85 (42\%) were girls in the control group. Chi-square test was done to know the frequency of fingerprint pattern in each digit of boys and girls in caries and caries-free group. Mann-Whitney U test was used to evaluate the fingerprint patterns among caries and control group; p-value $(<0.001)$ was calculated, and the results obtained were tested for statistical significance.

\section{Fingerprint Pattern in Boys}

In caries group of boys on the left fourth digit, $79.1 \%$ had whorls, $14.8 \%$ had ulnar loop, 5.2\% had arch, and $0.9 \%$ had radial loop, whereas caries-free group of boys showed $31.3 \%$ of arch, $30.4 \%$ of ulnar loop, $22.6 \%$ of radial loop, and $15.7 \%$ of whorls, which was statistically significant $(<0.001)$. On the left third digit of caries group of boys, 33.9\% had whorls and ulnar loop, 13.1\% had radial loop, and $19.1 \%$ had arch, whereas caries-free group of boys showed $27 \%$ and $22.6 \%$ of whorls and ulnar loop, $38.3 \%$ of arch, and $12.2 \%$ of radial loop, which was not statistically significant $(0.012) ; 30.4 \%$ of caries group boys and $22.6 \%$ caries-free group of boys had whorls and ulnar loop on left second digit. However, it was statistically not significant (0.01) (Table 1).

In caries group of boys on the left second digit, $30.4 \%$ had whorls, $27.0 \%$ had ulnar loop, $27.8 \%$ had arch, and $14.8 \%$ had radial loop, whereas caries-free group of boys showed $48.7 \%$ of arch, $22.6 \%$ of ulnar loop, $10.4 \%$ of radial loop, and $18.3 \%$ of whorls, which was statistically not significant (0.01). In caries group of boys on the left first digit, 33.0\% had whorls, $23.5 \%$ had ulnar loop, $27 \%$ had arch, and $16.5 \%$ had radial loop, whereas caries-free

Table 1: Frequency of fingerprint pattern in boys

\begin{tabular}{|c|c|c|c|c|}
\hline \multirow[b]{2}{*}{ Digit } & \multirow{2}{*}{$\begin{array}{l}\text { Fingerprint } \\
\text { pattern }\end{array}$} & $\begin{array}{l}\text { Caries } \\
\text { group }\end{array}$ & $\begin{array}{l}\text { Caries-free } \\
\text { group }\end{array}$ & \multirow[b]{2}{*}{$p$-value } \\
\hline & & $n(\%)$ & $n(\%)$ & \\
\hline \multirow[t]{4}{*}{ Left 4th digit } & Whorls & $91(79.1)$ & $18(15.7)$ & $<0.001$ \\
\hline & Ulnar loop & $17(14.8)$ & $36(30.4)$ & \\
\hline & Radial loop & $1(0.9)$ & $26(22.6)$ & \\
\hline & Arch & $6(5.2)$ & 35 (31.3) & \\
\hline \multirow[t]{4}{*}{ Left 3rd digit } & Whorls & 39 (33.9) & $31(27.0)$ & 0.012 \\
\hline & Ulnar loop & 39 (33.9) & $26(22.6)$ & \\
\hline & Radial loop & $15(13.1)$ & $14(12.2)$ & \\
\hline & Arch & $22(19.1)$ & $44(38.3)$ & \\
\hline \multirow[t]{4}{*}{ Left 2nd digit } & Whorls & $35(30.4)$ & $21(18.3)$ & 0.01 \\
\hline & Ulnar loop & $31(27.0)$ & $26(22.6)$ & \\
\hline & Radial loop & $17(14.8)$ & $12(10.4)$ & \\
\hline & Arch & $32(27.8)$ & $56(48.7)$ & \\
\hline \multirow[t]{4}{*}{ Left 1st digit } & Whorls & $38(33.0)$ & $17(14.8)$ & 0.024 \\
\hline & Ulnar loop & $27(23.5)$ & $27(23.5)$ & \\
\hline & Radial loop & $19(16.5)$ & $19(16.5)$ & \\
\hline & Arch & $31(27.0)$ & $52(45.2)$ & \\
\hline \multirow[t]{4}{*}{ Left thumb } & Whorls & $33(28.7)$ & $18(15.7)$ & 0.22 \\
\hline & Ulnar loop & $27(23.5)$ & $33(28.7)$ & \\
\hline & Radial loop & $24(20.9)$ & $20(17.4)$ & \\
\hline & Arch & $31(27.0)$ & $44(38.3)$ & \\
\hline \multirow[t]{4}{*}{ Right 4th digit } & Whorls & $38(33.0)$ & $28(24.3)$ & 0.087 \\
\hline & Ulnar loop & $29(25.2)$ & $24(20.9)$ & \\
\hline & Radial loop & $18(15.7)$ & $17(14.8)$ & \\
\hline & Arch & $30(26.1)$ & $46(40.0)$ & \\
\hline \multirow[t]{4}{*}{ Right 3rd digit } & Whorls & 87 (75.7) & $9(7.8)$ & $<0.001$ \\
\hline & Ulnar loop & $19(16.5)$ & $29(25.2)$ & \\
\hline & Radial loop & $5(4.3)$ & $12(10.4)$ & \\
\hline & Arch & $4(3.5)$ & $65(56.5)$ & \\
\hline \multirow[t]{4}{*}{ Right 2nd digit } & Whorls & 39 (33.9) & $15(13.0)$ & 0.096 \\
\hline & Ulnar loop & $23(20.0)$ & $44(38.3)$ & \\
\hline & Radial loop & $21(18.3)$ & $12(10.4)$ & \\
\hline & Arch & $32(27.8)$ & $44(38.3)$ & \\
\hline \multirow[t]{4}{*}{ Right 1st digit } & Whorls & $26(22.6)$ & $16(13.9)$ & 0.284 \\
\hline & Ulnar loop & $36(31.3)$ & $35(30.4)$ & \\
\hline & Radial loop & $17(14.8)$ & $24(20.9)$ & \\
\hline & Arch & 36 (31.3) & $40(34.8)$ & \\
\hline \multirow[t]{4}{*}{ Right thumb } & Whorls & $34(29.6)$ & $21(18.3)$ & 0.237 \\
\hline & Ulnar loop & $33(28.7)$ & $34(29.6)$ & \\
\hline & Radial loop & $14(12.2)$ & $15(13.0)$ & \\
\hline & Arch & $34(29.6)$ & $45(39.1)$ & \\
\hline
\end{tabular}


group of boys showed $45.2 \%$ of arch, $23.5 \%$ of ulnar loop, $16.5 \%$ of radial loop, and $14.8 \%$ of whorls, which was statistically not significant (0.024). In caries group of boys on left thumb, $28.7 \%$ had whorls, $23.5 \%$ had ulnar loop, $27 \%$ had arch, and $20.9 \%$ had radial loop, whereas caries-free group of boys showed $38.3 \%$ of arch, $28.7 \%$ of ulnar loop, $17.4 \%$ of radial loop, and $15.7 \%$ of whorls, which was statistically not significant (0.22). On the right fourth digit of boys in caries group, 33\% had whorls, $25.2 \%$ had ulnar loop, $15.7 \%$ had radial loop, and $26.1 \%$ had arch; $24.3 \%$ of whorls, $20.9 \%$ of ulnar loop, $14.8 \%$ of radial loop and $40 \%$ of arch were noticed in caries-free group. However, it was statistically not significant (0.087).

However, there was significant difference noticed on the right third digit; $75.7 \%$ caries group had whorls, $16.5 \%$ had ulnar loop, $4.3 \%$ had radial loop, 3.5\% had arches and in caries-free group, $7.8 \%$ had whorls, $56.5 \%$ had arch, $10.4 \%$ had radial loop, and $25.2 \%$ had ulnar loop. On the right second digit of boys in caries group, $33.9 \%$ had whorls, $20 \%$ had ulnar loop, $18.3 \%$ had radial loop, and $27.8 \%$ had arch; $13 \%$ of whorls, $38.3 \%$ of ulnar loop, $10.4 \%$ of radial loop, and $38.3 \%$ of arch were noticed in caries-free group. However, it was statistically not significant (0.096).

On the right first digit, 31.3\% had arch and ulnar loop pattern, $22.6 \%$ had whorls, and $14.8 \%$ had radial loop in caries group of boys, whereas in caries-free group, $34.8 \%$ had arch, $30.4 \%$ had ulnar loop, $13.9 \%$ had whorls, and $20.9 \%$ had radial loop, which was statistically not significant $(0.284) ; 29.6 \%$ of arch and whorls, $28.7 \%$ of ulnar loop, and $12.2 \%$ of radial loop was seen on the right thumb of caries group, whereas in caries-free group, $39.1 \%$ had arch, $29.6 \%$ had ulnar loop, $18.3 \%$ had whorls, and $13 \%$ had radial loop. However, it was statistically not significant (0.237).

\section{Fingerprint Pattern in Girls}

In caries group of girls on the left fourth digit, $23.5 \%$ had whorls, 38.8\% had ulnar loop, $16.5 \%$ had radial loop, and $21.2 \%$ had arch, whereas in caries-free group $10.6 \%$ had whorls, $49.4 \%$ had ulnar loop, $7.1 \%$ had radial loop, and $32.9 \%$ had arch, which was statistically not significant (0.014) (Table 2).

On the left third digit of caries group of girls, $72.9 \%$ had whorls, $17.6 \%$ had ulnar loop, $0 \%$ had radial loop, and $9.4 \%$ had arch; $47.1 \%$ of ulnar loop, $25.9 \%$ of arch, $24.7 \%$ of whorls, and $2.4 \%$ radial loop were seen in cariesfree group, which was statistically significant. On the left second digit of caries group of girls, $22.4 \%$ had whorls, $35.3 \%$ had ulnar loop, $15.3 \%$ had radial loop, and $27.1 \%$ had arch; $54.1 \%$ of ulnar loop, $15.3 \%$ of arch, $23.5 \%$ of whorls, and $7.1 \%$ radial loop were seen in caries-free group, which was statistically not significant (0.033).
Table 2: Frequency of fingerprint pattern in girls

\begin{tabular}{|c|c|c|c|c|}
\hline \multirow[b]{2}{*}{ Digit } & \multirow{2}{*}{$\begin{array}{l}\text { Fingerprint } \\
\text { pattern }\end{array}$} & $\begin{array}{l}\text { Caries } \\
\text { group }\end{array}$ & $\begin{array}{l}\text { Caries-free } \\
\text { group }\end{array}$ & \multirow[b]{2}{*}{$p$-value } \\
\hline & & $n(\%)$ & $n(\%)$ & \\
\hline \multirow[t]{4}{*}{ Left 4th digit } & Whorls & $20(23.5)$ & $9(10.6)$ & 0.014 \\
\hline & Ulnar loop & $33(38.8)$ & $42(49.4)$ & \\
\hline & Radial loop & $14(16.5)$ & $6(7.1)$ & \\
\hline & Arch & $18(21.2)$ & $28(32.9)$ & \\
\hline \multirow[t]{4}{*}{ Left 3rd digit } & Whorls & 62 (72.9) & $21(24.7)$ & $<0.001$ \\
\hline & Ulnar loop & 15 (17.6) & $40(47.1)$ & \\
\hline & Radial loop & $0(0.0)$ & $2(2.4)$ & \\
\hline & Arch & $8(9.4)$ & $22(25.9)$ & \\
\hline \multirow[t]{4}{*}{ Left 2nd digit } & Whorls & $19(22.4)$ & $20(23.5)$ & 0.033 \\
\hline & Ulnar loop & $30(35.3)$ & $46(54.1)$ & \\
\hline & Radial loop & $13(15.3)$ & $6(7.1)$ & \\
\hline & Arch & $23(27.1)$ & $13(15.3)$ & \\
\hline \multirow[t]{4}{*}{ Left 1st digit } & Whorls & $28(32.9)$ & $26(30.6)$ & $<0.001$ \\
\hline & Ulnar loop & $16(18.8)$ & $46(54.1)$ & \\
\hline & Radial loop & $20(23.5)$ & $2(2.4)$ & \\
\hline & Arch & $21(24.7)$ & $11(12.9)$ & \\
\hline \multirow[t]{4}{*}{ Left thumb } & Whorls & $33(38.8)$ & 35 (41.2) & $<0.001$ \\
\hline & Ulnar loop & $15(17.6)$ & $45(52.9)$ & \\
\hline & Radial loop & $15(17.6)$ & $0(.0)$ & \\
\hline & Arch & $22(25.9)$ & $5(5.9)$ & \\
\hline \multirow[t]{4}{*}{ Right 4th digit } & Whorls & $26(30.6)$ & 35 (41.2) & $<0.001$ \\
\hline & Ulnar loop & $22(25.9)$ & 37 (43.5) & \\
\hline & Radial loop & $17(20.0)$ & $0(.0)$ & \\
\hline & Arch & $20(23.5)$ & $13(15.3)$ & \\
\hline \multirow[t]{4}{*}{ Right 3rd digit } & Whorls & $29(34.1)$ & $4(4.7)$ & $<0.001$ \\
\hline & Ulnar loop & $20(23.5)$ & $60(70.6)$ & \\
\hline & Radial loop & $17(20.0)$ & $4(4.7)$ & \\
\hline & Arch & $19(22.4)$ & $17(20.0)$ & \\
\hline \multirow[t]{4}{*}{ Right 2nd digit } & Whorls & $26(30.6)$ & $7(8.2)$ & $<0.001$ \\
\hline & Ulnar loop & $22(25.9)$ & 49 (57.6) & \\
\hline & Radial loop & 15 (17.6) & $0(.0)$ & \\
\hline & Arch & $22(25.9)$ & $29(34.1)$ & \\
\hline \multirow[t]{4}{*}{ Right 1st digit } & Whorls & $31(36.5)$ & $7(8.2)$ & $<0.001$ \\
\hline & Ulnar loop & $18(21.2)$ & $41(48.2)$ & \\
\hline & Radial loop & $11(12.9)$ & $22(25.9)$ & \\
\hline & Arch & $25(29.4)$ & 15 (17.6) & \\
\hline \multirow[t]{4}{*}{ Right thumb } & Whorls & $32(37.6)$ & $33(38.8)$ & $<0.001$ \\
\hline & Ulnar loop & $20(23.5)$ & $38(44.7)$ & \\
\hline & Radial loop & $11(12.9)$ & $13(15.3)$ & \\
\hline & Arch & $22(25.9)$ & $1(1.2)$ & \\
\hline
\end{tabular}

However, on the left first digit of caries group, 32.9\% had whorls, $18.8 \%$ had ulnar loop, $23.5 \%$ had radial loop, and $24.7 \%$ had arch. In caries-free group, 54.1\% had ulnar loop, 30.6\% had whorls, $12.9 \%$ had arch, and $2.4 \%$ had radial loop, which was statistically significant. The left thumb of caries group of girls showed increase in frequency of whorls $(38.8 \%)$, arch $(25.5 \%)$, followed by ulnar loop and radial loop (17.6\%); $41.2 \%$ of whorls, $52.9 \%$ of ulnar loop, $5.9 \%$ of arch, and $0 \%$ of radial loop were noticed in caries-free group, which was statistically significant. In caries group of girls on the right fourth 
digit, $30.6 \%$ had whorls, $25.9 \%$ had ulnar loop, $20 \%$ had radial loop, and $23.5 \%$ had arch.

In caries-free group, $43.5 \%$ had ulnar loop, $41.2 \%$ had whorls, $0 \%$ had radial loop, $15.3 \%$ had arch, which was statistically significant. On the right third digit of caries group of girls, $34.1 \%$ had whorls, $23.5 \%$ had ulnar loop, $20 \%$ had radial loop, and $22.4 \%$ had arch; $70.6 \%$ of ulnar loop, $20 \%$ of arch, $4.7 \%$ of whorls, and $4.7 \%$ radial loop were seen in caries-free group, which was statistically significant. On the second right digit of caries group, $30.6 \%$ whorls, $25.9 \%$ ulnar loop and arch, and $17.6 \%$ radial loop were seen.

In caries-free group of girls, $57.6 \%$ had ulnar loop, $34.1 \%$ had arch, $8.2 \%$ had whorls, and $0 \%$ had radial loop, which was statistically significant. On the right first digit of caries group, $36.5 \%$ had whorls, $21.2 \%$ had ulnar loop, $12.9 \%$ had radial loop, and $29.4 \%$ had arch. In caries-free group, $48.2 \%$ had ulnar loop, $8.2 \%$ had whorls, $17.6 \%$ had arch, and $25.9 \%$ had radial loop, which was statistically significant.

The right thumb of caries group of girls showed increase in frequency of whorls $(37.6 \%)$, arch $(25.9 \%)$, followed by ulnar loop (23.5\%) and radial loop (12.9\%); $38.8 \%$ of whorls, $44.7 \%$ of ulnar loop, $15.3 \%$ of radial loop, and $1.2 \%$ of arch noticed in caries-free group, which was statistically significant.

\section{Mean and Standard Deviation of Caries and Caries-free Group (Mann-Whitney U test)}

The mean of whorls was $2.83 \pm 1.36$ standard deviation (SD) in caries group, whereas the mean of whorls was $2.02 \pm 1.34$ SD in caries-free group, which was statistically significant. The mean of ulnar loop was $3.04 \pm 1.52 \mathrm{SD}$ in caries group (Table 3).

The mean of ulnar loop was $3.63 \pm 1.91$ SD in cariesfree group, which was statistically significant $(\mathrm{p}<0.001)$. The mean of radial loop was $1.42 \pm 1.11 \mathrm{SD}$ in caries group and the mean of radial loop was $1.22 \pm 1.10 \mathrm{SD}$ in caries-free group, which was statistically not significant (p-value 0.068). The mean of arch in caries group was $2.71 \pm 1.32 \mathrm{SD}$ and the mean of arch in caries-free group was $3.13 \pm 2.04 \mathrm{SD}$ in caries-free group, which was statistically not significant ( $\mathrm{p}$-value 0.048 ).

Table 3: Mean and SD of caries and caries-free group (Mann-Whitney $U$ test)

\begin{tabular}{|c|c|c|c|}
\hline \multirow{3}{*}{$\begin{array}{l}\text { Fingerprint } \\
\text { pattern }\end{array}$} & \multicolumn{2}{|c|}{ Group } & \multirow[b]{3}{*}{$p$-value } \\
\hline & Caries & Caries-free & \\
\hline & Mean \pm SD & Mean \pm SD & \\
\hline Whorls & $2.83 \pm 1.36$ & $2.02 \pm 1.34$ & $<0.001$ \\
\hline Ulnar loop & $3.04 \pm 1.52$ & $3.63 \pm 1.91$ & $<0.001$ \\
\hline Radial loop & $1.42 \pm 1.11$ & $1.22 \pm 1.10$ & 0.068 \\
\hline Arch & $2.71 \pm 1.32$ & $3.13 \pm 2.04$ & 0.048 \\
\hline
\end{tabular}

Table 4: Total ridge count

\begin{tabular}{ll}
\hline Group & Percentage \\
\hline Caries males & 21 \\
Caries females & 27 \\
Caries-free males & 29 \\
Caries-free females & 23 \\
\hline
\end{tabular}

\section{Total Ridge Count}

The total ridge count in caries males was $21 \%$, in caries females was $27 \%$, caries-free females was $23 \%$, and cariesfree males was $29 \%$. Caries group showed decreased total ridge count especially in males than caries-free group (Table 4).

\section{DISCUSSION}

For many years, the fingerprints have caught the interest of various scholars, laymen, and doctors. The interpretation of palms has gone through various phases like popular image of traditional palmist interpreting incantation language to various scientific research. Palm prints have proven to be a powerful tool in the diagnosis of various medical disorders. ${ }^{11}$

Congenital abnormalities and IU anomalies can be detected with the help of dermatoglyphics. Fingerprints are oral health markers that can detect the genetic predisposition of children to dental caries. This is due to genetic inheritance with morphology of tooth, flow, and $\mathrm{pH}$ of saliva and enzymes of saliva.

The epidermal ridges of hands and facial structures are formed from ectoderm during 6 to 9 weeks of IU life. Hence, any changes that influence genetic and environmental factors responsible for causing dental caries may also cause change in fingerprint pattern. ${ }^{12}$

Fingerprints are unique and are based on the genetic characteristics of each individual. These dermal patterns once formed remain constant throughout life. The pathogenesis of caries process is rather well understood today, and caries attack rate in humans is a consequence of various attributes. Genetically regulated process is identified as contributing to caries incidence including tooth eruption, tooth morphology, density, or structural integrity of the enamel, composition of the secretion of salivary glands and salivary flow, the immune response, and reduction in the clearance of the bacteria. ${ }^{13}$

Dental caries demonstrates the graded continuous variation pattern, where sharp distinction between the average and high afflictions is not possible. Henceforth, only two extreme differences, such as "no caries" and caries on "three or more teeth" may be expected to demonstrate noticeable variation. Hence, the subjects in our group were divided into caries and caries-free group. Children with syndrome were not included in the study 
as they have a peculiar pattern, and oral hygiene maintenance is difficult in them as compared with healthy individuals.

The age group of 5 to 12 years was chosen to have a larger children base. Similar age group was selected by Vijender et al. ${ }^{11}$ In this study, dermatoglyphic data were collected in accordance with the method given by Cummins and Midlo by rolling impression technique using ink stamp, as prescribed by the Kentucky State Police, USA. Another method of recording fingerprint is by taking alginate impression of hands and pour it in dye stone. However, this method is expensive. Scanners, biometric machines, and photographs are the other methods of recording fingerprints. ${ }^{10}$

Fingerprint sample and DMFT score were recorded separately and the examiner was blinded. To reduce interexaminer variability, a single examiner did reading of all fingerprints. In this present study, frequency of whorl pattern was more in both males and females caries group. However, the frequency of whorl was more on the right third digit of males and on the left third digit of females. Our findings are in accordance with the study conducted by Madan et al, ${ }^{14}$ where whorls were seen more on the right third digit of males and on the left third digit of females.

Similar study conducted by Vijender et $\mathrm{al}^{11}$ showed increased frequency of whorls and decreased frequency of loops in caries-free group. There was an increase in frequency of arch noted in caries-free group of boys and an increase in frequency of ulnar loop noted in caries-free group of girls. These findings are in accordance with the study conducted by Madan et $\mathrm{al}^{14}$ where there was an increase in frequency of ulnar loop followed by whorl; arch and loop were noted in caries-free girls and arch pattern was noted in boys.

Similar study conducted by Vijender et $\mathrm{al}^{11}$ showed increased frequency of loop in caries-free group, which was statistically significant. A study conducted by Bhat et $\mathrm{al}^{15}$ among deaf and mute children showed the frequency of whorls to be more in caries group and loops in caries-free group. Similar study conducted among deaf and mute school children from Punjab showed an increased frequency of whorls in caries group. ${ }^{16}$

Abhilash et $\mathrm{al}^{17}$ concluded that dental caries susceptibility of an individual increased with incidence of whorl pattern and decreased with incidence of loop pattern. Individuals with high resistance to dental caries had a specific immunoglobulin within saliva conveying immunity by lysing the cariogenic bacterial cells. It was suggested that this phenotype was inherited and transmitted as an autosomal dominant trait. Several reports and studies also had shown significant heritability for several microorganisms, including streptococci. Thus, genes and genetic abnormalities that lead to abnormal structural organization of teeth and its environment lead to increased susceptibility to dental caries. Few studies have also reported that study subjects with dental caries had lower frequency of loops and higher growth of Streptococcus mutans as compared with control group. ${ }^{12}$

The quantitative analysis of total ridge count was more in caries-free children than caries group. Similar findings were noticed in a study conducted by $\mathrm{Atasu}^{18}$ and Madan. ${ }^{14}$

\section{Limitations of the Study}

Only one school from Warangal was considered, whereas large sample size would show more accurate results. It is difficult to say if genetic or environmental factor plays a dominating role in caries occurrence.

\section{CONCLUSION}

Based on our study, the results suggest that specific fingerprint pattern can be used for screening of dental caries and for guiding future research. Dermatoglyphics could be an appropriate method to explore the possibility of a noninvasive and an early predictor for dental caries.

\section{REFERENCES}

1. Tinanoff N, Kanellis MJ, Vargas CM. Current understanding of the epidemiology mechanisms, and prevention of dental caries in preschool children. Pediatr Dent 2002 Nov-Dec;24(6):543-551.

2. Thibodeau EA, O'Sullivan DM. Salivary mutans Streptococci and dental caries patterns in pre-school children. Community Dent Oral Epidemiol 1996 Jun;24(3):164-168.

3. Allukian M Jr. The neglected epidemic and the surgeon general's report: a call to action for better oral health. Am J Public Health 2000 Jun;90(6):843-845.

4. Masuda N, Tsutsumi N, Sobue S, Hamada S. Longitudinal survey of the distribution of various serotypes of Streptococcus mutans in infants. J Clin Microbiol 1979 Oct;10(4):497-502.

5. Spence MA, Elston RC, Namboodiri KK, Pollitzer WS. Evidence for a possible major gene effect in absolute finger ridge count. Hum Hered 1973;23(5):414-421.

6. Lin $\mathrm{CH}$, Liu JH, Osterburg JW, Nicol JD. Fingerprint comparison. I: Similarity of fingerprints. J Forensic Sci 1982 Apr;27(2):290-304.

7. Mavalwala J. Harold Cummins - and the birth, growth and development of dermatoglyphics. Am J Phys Anthropol 1975 Mar;42(2):177-181.

8. Penrose LS. Fingerprints and palmistry. Lancet 1973;1(7814): 1239-1242.

9. Penrose LS. Medical significance of finger-prints and related phenomena. Br Med J 1968 May;2(5601):321-325.

10. Tikare S, Rajesh G, Prasad KW, Thippeswamy V, Javali SB. Dermatoglyphics - a marker for malocclusion? Int Dent J 2010 Aug;60(4):300-304.

11. Vijender V, Tarannum T, Pathak A. Dermatoglyphics interpretation of dental caries: An in vivo Study. Int J Dent Med Res 2015;1(6):54-56. 
12. Sharma A, Somani R. Dermatoglyphic interpretation of dental caries and its correlation to salivary bacteria interactions: an in vivo study. J Indian Soc Pedod Prev Dent 2009 Jan-Mar;27(1):17-21.

13. Miller JR, Giroux J. Dermatoglyphics in pediatric practice. J Pediatr 1966 Aug;69(2):302-312.

14. Madan N, Rathnam A, Bajaj N. Palmistry: a tool for dental caries prediction! Indian J Dent Res 2011 Mar-Apr;22(2): 213-218.

15. Bhat PK, Badiyani BK, Aruna CN, Chengapa S, Bhaskar NN. Dermatoglyphics - a new diagnostic tool in detection of dental caries among deaf and mute children. Int J Clin Dent Sci 2011 Nov;2(4):80-84.

16. Sharma A, Singh P, Sood V. Palmar and digital dermatoglyphics in congenitally deaf subjects. J Punjab Acad Forensic Med Toxicol 2007;7(1):10-12.

17. Abhilash PR, Divyashree R, PatilSG, Gupta M, Chandrasekar T, Karthikeyan R. Dermatoglyphics in patients with dental caries: a study on 1250 individuals. J Contemp Dent Pract 2012 May;13(3):266-274.

18. Atasu M. Dermatoglyphic findings in dental caries: a preliminary report. J Clin Pediatr Dent 1998 Winter;22(2):147-149. 